\title{
Neutralization of Dengue Virus Serotypes by Sera from Dengue-Infected Individuals Is Preferentially Directed to Heterologous Serotypes and Not against the Autologous Serotype Present in Acute Infection
}

\author{
Heidi Auerswald ${ }^{1,2}{ }^{\mathbb{D}}$, Simone Kann ${ }^{1}$, Leonard Klepsch ${ }^{1} \mathbb{D}^{\mathbb{D}}$, Janne Hülsemann ${ }^{1}$, Ines Rudnik ${ }^{1}$, \\ Sebastian Schreiber ${ }^{1}$, Philippe Buchy ${ }^{2,3}$ and Michael Schreiber ${ }^{1, *}$ \\ 1 Department of Virology, Bernhard Nocht Institute for Tropical Medicine, 20359 Hamburg, Germany; \\ hauerswald@pasteur-kh.org (H.A.); simone.kann@medmissio.de (S.K.); leonardklepsch@gmail.com (L.K.); \\ janne.huelsemann@posteo.de (J.H.); ines.rudnik@haw-hamburg.de (I.R.); sebastian@schryber.com (S.S.) \\ 2 Virology Unit, Institut Pasteur in Cambodia, Phnom Penh 12201, Cambodia; philippe.x.buchy@gsk.com \\ 3 GlaxoSmithKline, Vaccines R\&D, Singapore 139234, Singapore \\ * Correspondence: Michael.Schreiber@bnitm.de
}

check for updates

Citation: Auerswald, H.; Kann, S.; Klepsch, L.; Hülsemann, J.; Rudnik, I.; Schreiber, S.; Buchy, P.; Schreiber, M. Neutralization of Dengue Virus Serotypes by Sera from Dengue-Infected Individuals Is Preferentially Directed to Heterologous Serotypes and Not against the Autologous Serotype Present in Acute Infection. Viruses 2021, 13, 1957. https://doi.org/ 10.3390/v13101957

Academic Editor: Karla Helbig

Received: 3 September 2021

Accepted: 27 September 2021

Published: 29 September 2021

Publisher's Note: MDPI stays neutral with regard to jurisdictional claims in published maps and institutional affiliations.

Copyright: (c) 2021 by the authors. Licensee MDPI, Basel, Switzerland. This article is an open access article distributed under the terms and conditions of the Creative Commons Attribution (CC BY) license (https:// creativecommons.org/licenses/by/ $4.0 /)$.

\begin{abstract}
Sequential infections of humans by the four different dengue serotypes (DENV-1-4) lead to neutralizing antibodies with group, cross, and type specificity. Virus neutralization of serotypes showed monotypic but mostly multitypic neutralization profiles due to multiple virus exposures. We have studied neutralization to heterologous, reference DENV serotypes using paired sera collected between days 6 and 37 after onset of fever. The DENV-primed neutralization profile of the first serum sample, which was monitored by a foci reduction neutralization test (FRNT), was boosted but the neutralization profile stayed unchanged in the second serum sample. In 45 of 47 paired serum samples, the predominant neutralization was directed against DENV serotypes distinct from the infecting serotype. Homologous neutralization studies using sera and viruses from the same area, 33 secondary sera from DENV-1 infected Cambodian patients and eight virus isolates from Cambodia, showed that the FRNT assay accurately predicted the lack of a predominant antibody response against the infecting DENV-1 serotype in contrast to FRNT results using the WHO set of DENV viruses. This report provides evidence that DENV-primed multitypic neutralizing antibody profiles were mainly boosted and stayed unchanged after secondary infection and that DENV neutralization was predominantly directed to heterologous DENV but not against the infecting homologous serotype.
\end{abstract}

Keywords: dengue virus; neutralization; serotype; antigen assay; domain 3; E protein

\section{Introduction}

Dengue viruses (DENV), as part of the family Flaviviridae, represent an antigenic subgroup in the genus Flavivirus [1]. They are characterized by a distinctive genetic variability and are classified into four subspecies, designated DENV-1 to DENV-4. Subtyping of DENV has been historically performed by serotyping-a method in which DENVs are antigenically differenced based on reactions with DENV type-specific antibodies by plaque reduction neutralization tests (PRNT) [2], indirect immunofluorescence (IFA) [3,4], or enzyme-linked immunosorbent assays (ELISA) [5]. Today, serotyping has been developed based on viral RNA detection [6]. Thus, instead of antigenic differences, genetic differences are used to differentiate between the four so-called DENV serotypes. Nevertheless, our understanding on dengue virus variation might be inchoate, since DENVs cluster more based on their antigenic properties [7,8] rather than as distinct genetically defined serotypes [9]. In general, the effect of antigenic variation by amino acid substitutions cannot easily be predicted from virus sequences. Single substitutions can improve antibody binding, but sometimes, multiple amino acid substitutions are necessary to produce the same viral 
phenotype and vice versa. Therefore, differences in viral phenotypes and the capacity to neutralize DENV must be tested by antibody neutralization assays using monoclonal, polyclonal, or serum antibodies [10-12].

In addition to the classification of DENV, it is an important task to study the potential of neutralizing antibodies in sera from DENV-infected patients against the different DENV subtypes, the so-called neutralization profile to DENVs. It is a matter of common knowledge that infection with a distinct DENV leads to a humoral immune response that protects patients against the infection with the homologous type but not against infection by heterologous virus [13-16]. Such a matching, type-specific homotypic response can be clearly seen in the primary infection of formerly naïve patients $[17,18]$. The situation becomes tremendously complex when the type-specificity of neutralizing antibodies is studied in secondary DENV infection in comparison to the infecting virus [19]. After secondary infection, individuals develop homotypic as well as multitypic neutralizing antibodies to DENVs in which the multitypic response, or multitypic neutralization profile, is directed against virus subtypes they had probably never been exposed to [12]. Thus, the anti-DENV humoral response is a combination of group-, cross-, and type-specific antibodies all binding to a variety of DENVs [20]. Detailed studies of polyclonal responses in human sera showed that the E protein is a target for group-, cross-, and type-specific antibodies whereby the latter, type-specific antibodies, represent only a very small minority of the total anti-E antibody response [20,21].

It is suggested that after secondary infection, the type-specific antibody response will become predominant, shifting to type-specificity directed against the infecting virus. However, it is thought that second serum samples, regularly collected between days 6 and 8 after the onset of fever, are collected too early to see those type-specific antibodies arising. The maturation of immune response and the difference in terms of reactivity between strains due to antigenic differences was previously studied in experimental infections. Monkeys were challenged with a variety of different virus isolates, and their immune response was measured. Monkey antisera could generally neutralize the autologous virus much better than heterologous types [22]. Interestingly, after sequential infection by different DENV serotypes, no solid immunity to dengue could be achieved [23]. The latter is an interesting study, since it is an autologous challenge and protection experiment that mimics more precisely natural infection in humans. It indicates that the DENV-primed immune response caused by the first infection is not sufficiently supplemented by the second virus to establish full protection.

A model of B cell maturation following sequential DENV infections proposed by Patel et al. [12] suggests that after secondary infection, the cross-specific response will be significantly boosted. Thus, with each new DENV infection, the ratio of type-specific and cross-reactive antibodies is getting smaller, leading to a decrease in type-specific responses and an increase in the cross-specific antibody population [12]. From these experiments, it can be concluded that the analysis of the DENV-specific neutralization profile in sequential serum samples will show a general boost of neutralization titers. However, this anti-DENV boost will not be accompanied by a shift to the highest neutralization titers directed against the last current DENV serotype.

This report aims to provide data on the DENV-specific neutralization profiles from heterologous and homologous neutralization experiments using serum samples collected between 3 and 37 days after onset of dengue fever. In addition, two indirect diagnostic assays (ED3 ELISA and ED3 dot assay) were performed to detect serotype-specific antibody responses in sera from DENV-infected patients, which were examined for a unique serotype by a direct virus assay (RT-PCR). From the comparison of data received from direct and indirect serotyping studies, it seems that the neutralizing antibody profile remains unchanged with the highest antibody response or neutralizing activity directed against a DENV serotype not in consistency with the serotype detected in acute infection. 


\section{Materials and Methods}

\subsection{Cell Culture}

VeroB4 cells were used for DENV cultivation as well as for the $90 \%$ foci reduction neutralization test $\left(\mathrm{FRNT}^{90}\right)$. VeroB4 cells were cultured in Dulbecco's modified Eagle's medium (DMEM), supplemented with 10\% FCS (fetal calf serum), 2 mM glutamine (PanBiotech, Aidenbach, Germany), 1\% antibiotic solution $(5000 \mathrm{U} / \mathrm{mL}$ penicillin, $5.000 \mu \mathrm{g} / \mathrm{mL}$ streptomycin; Gibco, USA) at $37^{\circ} \mathrm{C}$ and $5 \% \mathrm{CO}_{2}$.

\subsection{Viruses}

The DENV strains used for neutralization tests are summarized in Table 1. All viruses were cultivated in VeroB4 cells. Virus culture supernatants were harvested by centrifugation and concentrated with $8 \%$ PEG 8000 overnight at $4{ }^{\circ} \mathrm{C}$. Viruses were precipitated by centrifugation at $1500 \times g$ for $30 \mathrm{~min}$. The virus-containing pellets were suspended in DMEM and stored at $-80{ }^{\circ} \mathrm{C}$ until use.

Table 1. The three sets of dengue viruses used for the foci reduction neutralization test $\left(\mathrm{FRNT}^{90}\right)$.

\begin{tabular}{|c|c|c|c|c|}
\hline \multicolumn{5}{|c|}{ REF } \\
\hline DENV-1 & 16007 & Thailand & 1964 & Genbank AF180817 \\
\hline DENV-2 & 16681 & Thailand & 1984 & Genbank U87411.1 \\
\hline DENV-3 & H87 & Philippines & 1956 & Genbank M93130 \\
\hline DENV-4 & $\mathrm{H} 241$ & Philippines & 1956 & Genbank AB609591 \\
\hline \multicolumn{5}{|c|}{ IPC A } \\
\hline DENV-1 & KH/BID-V2004/2006 & Cambodia & 2006 & Genbank FJ639687 \\
\hline DENV-2 & D2KH/06PHP & Cambodia & 2006 & IPC virus isolate \\
\hline DENV-3 & KH/BID-V2058/2005 & Cambodia & 2005 & Genbank GQ868628 \\
\hline DENV-4 & D4KH/98PHP & Cambodia & 1998 & IPC virus isolate \\
\hline \multicolumn{5}{|c|}{ IPC B } \\
\hline DENV-1 & KH/BID-V2011/2007 & Cambodia & 2007 & Genbank FJ639693 \\
\hline DENV-2 & KH/BID-V2066/2007 & Cambodia & 2007 & Genbank FJ639717 \\
\hline DENV-3 & KH/BID-V2051/2007 & Cambodia & 2006 & Genbank FJ639713 \\
\hline DENV-4 & $\mathrm{D} 4 \mathrm{KH} / 07$ & Cambodia & 2007 & IPC virus isolate \\
\hline
\end{tabular}

REF, DENV reference strains; IPC A and IPC B, DENV isolated during the same epidemic season that the sera were collected; IPC, Institut Pasteur in Cambodia.

\subsection{Serum Specimens}

Dengue positive serum samples $(n=504)$ were provided by the Institut Pasteur in Cambodia (IPC). Sera were formerly characterized by RT-PCR, IgM MAC-ELISA, and HIA [17]. The use of stored and partially anonymized samples for research purposes was approved by the Cambodian National Ethics Committee. Paired serum samples $(n=7)$ from Colombia were collected from patients who were tested positive for dengue by a commercial RT-PCR (RealStar Dengue RT-PCR Kit 1.0, altona Diagnostics, Hamburg, Germany) in a study at the Hospital Rosario Pumarejo de Lopez in Valledupar, Colombia, which was approved by the local ethic commission.

\subsection{Foci Reduction Neutralization Test}

The foci reduction neutralization test $\left(\mathrm{FRNT}^{90}\right)$ was carried out as described earlier [24]. In brief, flat-bottom 96-well microplates were seeded with VeroB4 cells $\left(4 \times 10^{4}\right.$ per well) $24 \mathrm{~h}$ before infection. Serum dilutions starting at 1:10 were prepared in DMEM and added to equal volumes of virus supernatants. Virus-serum mixtures were incubated for one hour at $37^{\circ} \mathrm{C}$ and finally added to VeroB4 cells. After virus infection, a semi-solid overlay (0.8\% methyl cellulose, DMEM, 10\% FCS) was added, and the microplates were incubated for three days at $37^{\circ} \mathrm{C}$ followed by a treatment with formaldehyde solution (3.7\% in PBS (137 mM NaCl, $2.7 \mathrm{mM} \mathrm{KCl}, 10 \mathrm{mM} \mathrm{Na}_{2} \mathrm{HPO}_{4}, 1.8 \mathrm{mM} \mathrm{KH}_{2} \mathrm{PO}_{4}, \mathrm{pH} 7.4$ )). Microplates were washed with PBS followed by a PBS/0.5\% Triton X-100 treatment for 20 min at room 
temperature and washed again with PBS/10\% FCS. Infected cells were detected using anti-DENV mouse hyperimmune ascites fluids (IPC, Phnom Penh, Cambodia). Staining was performed using anti-mouse IgG antibody conjugated to horseradish peroxidase (Bio-Rad, München, Germany) and 3, 3', 5, 5'-tetramethylbenzidine as substrate (SureBlue $^{\text {TM }}$ TMB 1-component microwell peroxidase substrate, medac, Wedel, Germany). The stained cells (foci) were counted immediately, and the endpoint titers were expressed as reciprocal of the highest serum dilution showing $\geq 90 \%$ reduction in foci counts (FRNT ${ }^{90}$ titer) compared to wells without serum. All sera were tested in triplicate. The DENV serotype-specific antibody response was considered as the highest FRNT $^{90}$ titer to one of the DENV serotypes.

\subsection{Maltose Binding Protein-ED3 Fusion Proteins}

The ED3 domains were expressed in E. coli BL21 as a fusion to maltose-binding protein (MBP). The ED3 and ED3s domains of the WHO (World Health Organization) recommended DENV strains were cloned as described earlier [24]. The COL (Colombian dengue strains) ED3 domains were cloned using the assembly PCR method. The list of synthetic oligonucleotides (TIB Molbiol, Berlin, Germany) for the COL MBP-ED3 antigens is shown in Table A1. A mixture of $2 \mu \mathrm{L}$ for each oligonucleotide $(10 \mu \mathrm{M}), 0.6 \mathrm{~mL} \mathrm{dNTP}$ $(10 \mathrm{mM}), 6 \mu \mathrm{L}$ GC-buffer, and $0.3 \mu \mathrm{L}$ Taq-DNA-Polymerase (New England Biolabs, Frankfurt, Germany) in a total volume of $30 \mu \mathrm{L}$ was assembled using 10 temperature cycles of $98{ }^{\circ} \mathrm{C}(90 \mathrm{~s}), 56{ }^{\circ} \mathrm{C}(120 \mathrm{~s})$, and $72{ }^{\circ} \mathrm{C}(120 \mathrm{~s})$. From the assembly mixture, $0.4 \mu \mathrm{L}$ were given to $20 \mu \mathrm{L}$ GC-buffer, $1 \mu \mathrm{L}$ Taq-DNA-Polymerase (New England Biolabs, Frankfurt, Germany), $5 \mu \mathrm{L}$ forward (BamHI) primer $(10 \mu \mathrm{M}), 5 \mu \mathrm{L}$ reverse (HindIII) primer $(10 \mu \mathrm{M})$, and $2 \mu \mathrm{L}$ dNTP $(10 \mathrm{mM})$ in a total volume of $100 \mu \mathrm{L}$. The BamHI/HindIII DNA fragment was amplified using 45 temperature cycles of $98^{\circ} \mathrm{C}(50 \mathrm{~s}), 56{ }^{\circ} \mathrm{C}(60 \mathrm{~s})$, and $72{ }^{\circ} \mathrm{C}(120 \mathrm{~s})$. Amplified DNA was extracted from a $0.8 \%$ agarose gel (QIAquick Gel Extraction Kit, QIAGEN, Hilden, Germany). The purified DNA was cloned into the pCR2.1 plasmid (TA-Cloning Kit, Invitrogen, Dreieich, Germany) according to the manufacturer's recommendations. Positive clones were selected by white/blue screening on ampicillin/X-gal/IPTG plates and controlled by sequence analysis (LGC Genomics, Berlin, Germany). After BamHI and HindIII cleavage, the ED3 fragments were cloned into the MBP expression plasmid (pMal-p4x), and expression in E. coli BL21 was carried out as described earlier [24]. In brief, a volume of $2.7 \mathrm{~L}$ of dyt-medium supplemented with $300 \mu \mathrm{g} / \mathrm{mL}$ ampicillin, $0.5 \mathrm{mM} \mathrm{IPTG}$, and $0.2 \%$ glucose was inoculated 1:100 with an overnight culture and incubated at $37{ }^{\circ} \mathrm{C}$. Bacteria were harvested and treated with lysozyme $(5 \mathrm{mg} / \mathrm{mL})$ prior to sonication. Clear lysates were obtained after centrifugation at 15,000 $\times g$ (Eppendorf 5810R, rotor FA-45-6-30, Hamburg, Germany). The MBP-ED3 fusion proteins were purified from clear lysates using amylose resin affinity chromatography according to the manufacturer's recommendations (New England Biolabs, Frankfurt, Germany).

\subsection{ED3 Dot Assay}

A very detailed description of the ED3 dot assay was done earlier by Auerswald et al. [24]. Purified MBP-ED3 or MBP-ED3s fusion proteins $(1 \mathrm{mg} / \mathrm{mL})$ were used for the ED3 dot assay and the modified, SDS denatured form of ED3, designated mED3 or mED3s, was produced by adding SDS to a final concentration of $1 \%$ to the respective ED3 constructs, heated to $95{ }^{\circ} \mathrm{C}$ for $10 \mathrm{~min}$ and dotted, together with the other ED3 antigens $(0.5 \mu \mathrm{L}$, $1 \mathrm{mg} / \mathrm{mL})$, onto nitrocellulose strips $(2.7 \mathrm{~mm} \times 115 \mathrm{~mm}$, BA85, Schleicher \& Schuell, Dassel, Germany). After the dotting procedure, the test strips were transferred to a 30-well incubation tray (Viramed, Planegg, Germany) and were incubated with $1 \mathrm{~mL}$ PBST blocking buffer (PBS, 0.05\% Tween 20,5\% low fat milk) for $1 \mathrm{~h}$ at room temperature. The blocking buffer was replaced against the serum solution (1:100 in PBST, 5\% low fat milk) and incubated for $2 \mathrm{~h}$ on a shaker followed by three wash cycles with PBST. The detection of bound human antibodies was carried out using an anti-human IgG antibody conjugated to horseradish peroxidase (Bio Rad, Hercules, CA, USA) diluted 1:1000 in PBST blocking 
buffer. After $1 \mathrm{~h}$ of incubation, the test strips were washed again three times with PBST followed by three wash cycles with PBS. Bound antibodies were visible as dots after 10-20 min incubation with 4-chloro-1-naphtol $(4 \mathrm{CN})$ solution, a freshly prepared mixture of $200 \mathrm{~mL}$ PBS, $100 \mu \mathrm{L} \mathrm{H}_{2} \mathrm{O}_{2}$ (30\% stock solution, Merck, Darmstadt, Germany), and $40 \mathrm{~mL}$ $4 \mathrm{CN}$ solution $(0.3 \%$ in methanol). The intensity of the dots was analyzed by an in-house made purpose-built dot analyzing software (BlotLog) [24] or by using the universal graph digitizer software UN-SCAN-IT (Silk Scientific, Orem, UT, USA).

\subsection{ED3 ELISA}

The MBP-ED3 antigen concentration was adjusted to $2 \mu \mathrm{g} / \mathrm{mL}$ with bicarbonate/carbonate buffer (100 mM, pH 9.6). Plates with the diluted antigens, $100 \mu \mathrm{L}$ per well (96-well plate, Maxisorb, Greiner Bio-One, Frickenhausen, Germany), were sealed and incubated at $8{ }^{\circ} \mathrm{C}$ overnight. Sera, diluted 1:100, were pre-incubated to $\mathrm{MBP}(75 \mu \mathrm{g} / \mathrm{mL})$ at $8^{\circ} \mathrm{C}$ overnight. Prior to antibody testing, each antigen-coated well was additionally filled with $300 \mu \mathrm{L}$ blocking buffer (PBS, 5\% low fat milk), and the plates were incubated for $1 \mathrm{~h}$ at room temperature. Plates were washed three times with PBST, and in each well, $100 \mu \mathrm{L}$ of the serum-MBP mixture was added and incubated at room temperature for $1 \mathrm{~h}$. After antibody binding, the plates were again washed three times with PBST, and $100 \mu \mathrm{L}$ of HRP-conjugated goat anti-human anti-IgG antibody (Bio-Rad, Feldkirchen, Germany) diluted 1:2000 were added to each well and incubated for $1 \mathrm{~h}$. Plates were washed three times with PBST, followed by three wash cycles with PBS. To each well, $50 \mu \mathrm{L}$ of TMB substrate (KPL SureBlue, medac, Wedel, Germany) was added. The color reaction was stopped after $20 \mathrm{~min}$ by adding $50 \mu \mathrm{L}$ of TMB BlueSTOP solution (KPL, medac, Wedel, Germany). The intensity of the color reaction was measured at $640 \mathrm{~nm}$.

\section{Results}

\subsection{Comparison of Direct DENV Detection and Serotyping Using the ED3 Dot Assay}

Second serum samples were selected from the IPC Biobank with defined DENV serotype verification by RT-PCR. For each of the four DENV serotypes, 97-100 sera were chosen to be analyzed for the presence of DENV type-specific antibodies by the ED3 dot assay. The assay is using two antigens, recombinant mED3 and mED3s fused to maltose-binding protein (MBP).

From the DENV-1 infected group, all 97 sera showed antibody responses to one of the four serotypes with the most frequent response to the antigens representing the DENV-2 strain 16681 (Figure 1). More than $60 \%$ of the DENV-1 sera showed type-specific antibody response against the mED3 and mED3s DENV-2 antigens. Thus, for the majority of the DENV-1 sera, the predominant antibody response was directed against a DENV serotype different to the serotype present during infection. That the predominant antibody response was directed against a different serotype and not against the infecting serotype was also shown in the three other groups that were RT-PCR positive for DENV-2, DENV-3, and DENV-4.

In the DENV-2 group, the predominant antibody response was against the DENV-1 serotype, which was followed by DENV-3 and DENV-4. Only 7-10\% of the sera showed a matching DENV-2 response. In the DENV-3 group, the matching antibody response was in third place with a frequency of $12 \%$, followed by DENV-4 serotype specific neutralization with a frequency of $7-8 \%$. Thus, in total, $80 \%$ of the sera showed a non-matching antibody response with antibody responses highest for DENV-1 and DENV-2. In the DENV-4 group, predominant neutralization was observed mainly against DENV-1 followed by DENV-2 and DENV-3. None of the sera showed a matching antibody response in the DENV-4 group; thus, a 100\% mismatch between the infecting serotype and serotype-specific antibody was observed. Altogether, in all four groups, more than $85 \%$ of the sera showed a different serotype compared to the serotype identified during DENV infection (DENV-1 > 85\%; DENV-2 > 90\%, DENV-3 > 88\%, DENV-4 = 100\%). 


\section{Serotype by RT-PCR}

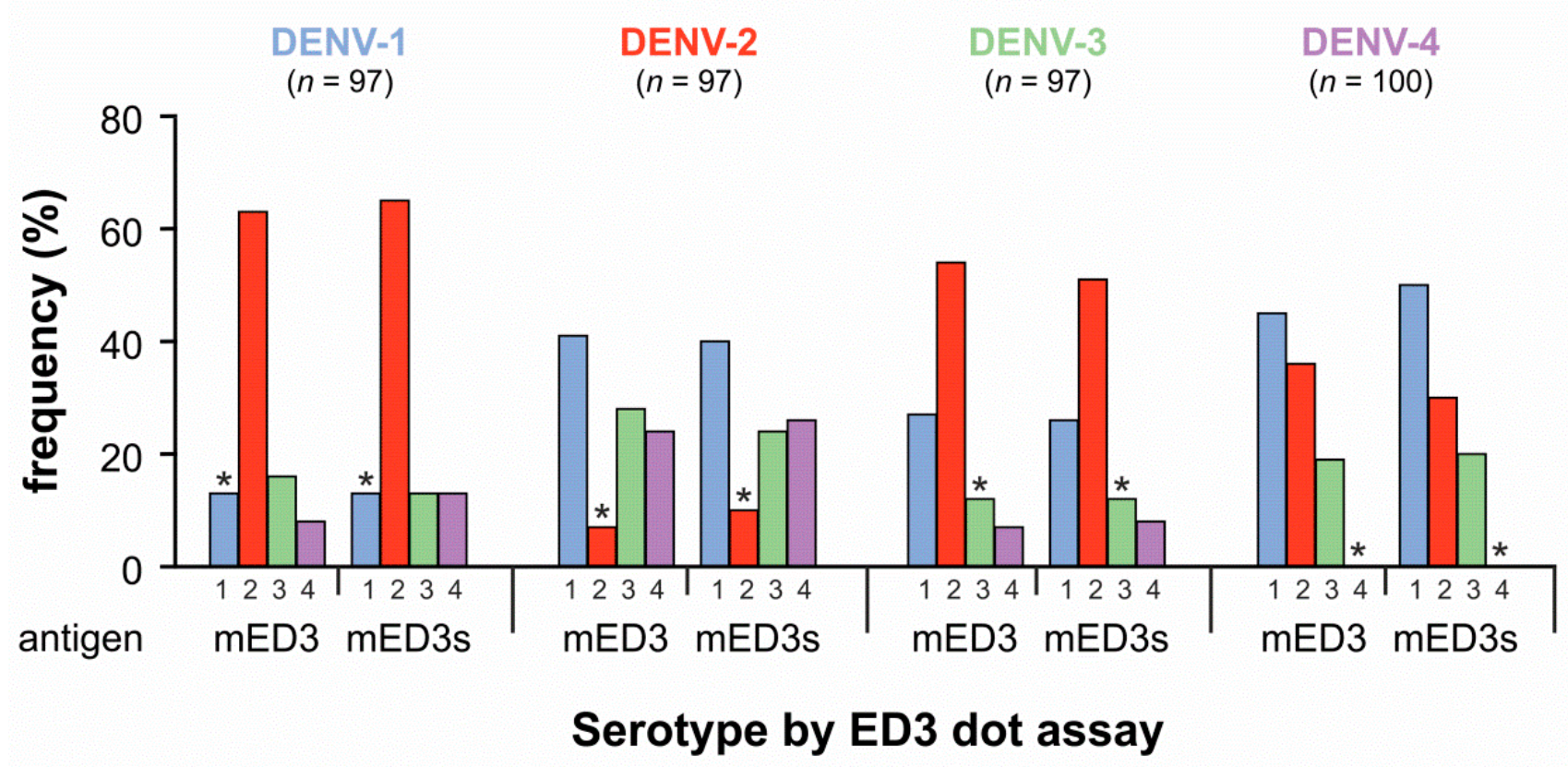

Figure 1. ED3-specific antibody detection by ED3 dot assay in RT-PCR defined sera. Sera were collected from Cambodian patients infected by DENV-1 $(n=97$, blue), DENV-2 $(n=97$, red), DENV-3 ( $n=97$, green), or DENV-4 ( $n=100$, purple). The ED3 dot assay was performed using mED3 and mED3s antigens representing ED3 amino acid sequences of DENV reference strains as given in Table 1. X-axis, numbers indicate DENV serotype tested by mED3 or mED3s antigens. ${ }^{*}$, indicating matching results.

\subsection{Neutralization of DENV by Sera from RT-PCR Diagnosed DENV Cases}

By using 40 DENV-positive paired serum samples from Cambodian patients, ten pairs for each DENV serotype as confirmed by RT-PCR, we wanted to investigate what is the highest neutralization titer (FRNT ${ }^{90}$ ) to one of the reference serotypes (listed in Table 1). In these experiments, the time frame between the onset of fever and the collection of the second serum was $7 \pm 1.4$ days.

When sera were tested for virus neutralization, the highest FRNT ${ }^{90}$ titers were observed against DENV serotypes that were not identical to the serotype present in acute infection (Table 2, marked in gray). For example, the paired sera (no. 01, Table 2) were from a DENV-1 infected patient, but the first serum showed the highest titer for neutralization against DENV-2 (1:5120) in contrast to DENV-1, where the titer was significantly four 2-fold dilutions lower (1:320). In the first serum, the serotype-specificity of the antibodies to DENV in decreasing titer magnitude was DENV-2 (1:5120), DENV-4 (1:2560), DENV-3 (1:640), and with the weakest FRNT ${ }^{90}$ titer for DENV-1 (1:320). In addition, in the second serum, the highest neutralization titer was observed for DENV-2 $(1: 20,480)$ followed by DENV-4 (1:5120). Thus, neutralization was highest for DENV-2 in both sera, and the neutralization profile to DENV-1-4 was unchanged, but neutralization titers were boosted. Such non-matching results between serotype by RT-PCR and serotype by FRNT ${ }^{90}$ were seen in 38 out of the 40 paired sera. Only two paired samples, no.09 and no.15 (Table 2), showed a matching antibody response to the corresponding reference strains. 
Table 2. Neutralization titers to DENV-1-4 reference strains using RT-PCR confirmed DENV sera.

\begin{tabular}{|c|c|c|c|c|c|c|c|c|c|}
\hline \multirow{3}{*}{\multicolumn{2}{|c|}{$\begin{array}{c}\text { Serotype by } \\
\text { RT-PCR }\end{array}$}} & \multicolumn{4}{|c|}{ FRNT $^{90}$, 1st Serum } & \multicolumn{4}{|c|}{ FRNT $^{90}$, 2nd Serum } \\
\hline & & \multicolumn{4}{|c|}{ DENV } & \multicolumn{4}{|c|}{ DENV } \\
\hline & & \multirow{2}{*}{$\begin{array}{c}1 \\
320\end{array}$} & \multirow{2}{*}{$\frac{2}{5120}$} & \multirow{2}{*}{$\frac{3}{640}$} & \multirow{2}{*}{$\frac{4}{2560}$} & \multirow{2}{*}{$\begin{array}{c}1 \\
640\end{array}$} & \multirow{2}{*}{$\frac{2}{20,480}$} & \multirow{2}{*}{$\frac{3}{640}$} & \multirow{2}{*}{$\frac{4}{5120}$} \\
\hline 01 & DENV-1 & & & & & & & & \\
\hline 02 & DENV-1 & 20 & 320 & 40 & 160 & 1280 & 20,480 & 5120 & 5120 \\
\hline 03 & DENV-1 & 80 & 1280 & 80 & 640 & 320 & 5120 & 640 & 5120 \\
\hline 04 & DENV-1 & 40 & 320 & 40 & 320 & 1280 & 20,480 & 320 & 2560 \\
\hline 05 & DENV-1 & $<20$ & 80 & 20 & 80 & 320 & 2560 & 160 & 2560 \\
\hline 06 & DENV-1 & 20 & 80 & 320 & 80 & 1280 & 2560 & 20,480 & 640 \\
\hline 07 & DENV-1 & 320 & 160 & 5120 & 320 & 320 & 320 & 5120 & 320 \\
\hline 08 & DENV-1 & $<20$ & $<20$ & $<20$ & $<20$ & 20 & $<20$ & $<20$ & 40 \\
\hline 09 & DENV-1 & $<20$ & $<20$ & $<20$ & $<20$ & 20 & $<20$ & $<20$ & $<20$ \\
\hline 10 & DENV-1 & 20 & 20 & 20 & 20 & 80 & 640 & 80 & 640 \\
\hline 11 & DENV-2 & 5120 & 320 & 80 & 320 & 20,480 & 2560 & 1280 & 5120 \\
\hline 12 & DENV-2 & 160 & 40 & 20 & 40 & 20,480 & 2560 & 1280 & 2560 \\
\hline 13 & DENV-2 & 2560 & 640 & 80 & 320 & 10,240 & 5120 & 640 & 1280 \\
\hline 14 & DENV-2 & 1280 & 640 & 160 & 640 & 2560 & 1280 & 160 & 1280 \\
\hline 15 & DENV-2 & 40 & 2560 & 640 & 1280 & 80 & 2560 & 640 & 1280 \\
\hline 16 & DENV-2 & 160 & 1280 & 2560 & 1280 & 320 & 2560 & 5120 & 2560 \\
\hline 17 & DENV-2 & 160 & 1280 & 2560 & 1280 & 640 & 2560 & 20,480 & 2560 \\
\hline 18 & DENV-2 & 160 & 640 & 1280 & 1280 & 640 & 2560 & 10,240 & 2560 \\
\hline 19 & DENV-2 & $<20$ & 160 & $<20$ & 1280 & 640 & 160 & 40 & 320 \\
\hline 20 & DENV-2 & 40 & 1280 & 20 & 2560 & 80 & 2560 & 40 & 5120 \\
\hline 21 & DENV-3 & 5120 & 640 & 1280 & 320 & 5120 & 320 & 1280 & 320 \\
\hline 22 & DENV-3 & 5120 & 1280 & 320 & 640 & 5120 & 2560 & 320 & 2560 \\
\hline 23 & DENV-3 & 2560 & 640 & 320 & 320 & 10,240 & 2560 & 5120 & 5120 \\
\hline 24 & DENV-3 & 5120 & 2560 & 80 & 1280 & 5120 & 10,240 & 640 & 5120 \\
\hline 25 & DENV-3 & 160 & 2560 & 20 & 1280 & 1280 & 5120 & 40 & 2560 \\
\hline 26 & DENV-3 & 320 & 5120 & 160 & 2560 & 5120 & 20,480 & 1280 & 20,480 \\
\hline 27 & DENV-3 & 160 & 5120 & 160 & 2560 & 160 & 5120 & 320 & 5120 \\
\hline 28 & DENV-3 & $<20$ & 320 & $<20$ & 40 & 40 & 160 & $<20$ & 40 \\
\hline 29 & DENV-3 & 640 & 5120 & 40 & 5120 & 640 & 5120 & 80 & 5120 \\
\hline 30 & DENV-3 & 320 & 10,240 & 320 & 5120 & 1280 & 5120 & 320 & 5120 \\
\hline 31 & DENV-4 & 1280 & 80 & 20 & 40 & 10,240 & 640 & 640 & 1280 \\
\hline 32 & DENV-4 & 320 & 40 & $<20$ & 40 & 10,240 & 10,240 & 2560 & 1280 \\
\hline 33 & DENV-4 & 5120 & 160 & 160 & 80 & 20,480 & 1280 & 1280 & 640 \\
\hline 34 & DENV-4 & 640 & 20 & 20 & 40 & 10,240 & 2560 & 1280 & 1280 \\
\hline 35 & DENV-4 & 10,240 & 1280 & 640 & 1280 & 20,480 & 2560 & 1280 & 5120 \\
\hline 36 & DENV-4 & 40 & 1280 & 160 & 640 & 320 & 5120 & 2560 & 2560 \\
\hline 37 & DENV-4 & 640 & 20,480 & 320 & 5120 & 640 & 20,480 & 640 & 10,240 \\
\hline 38 & DENV-4 & 640 & 320 & 1280 & 80 & 20,480 & 2560 & 20,480 & 1280 \\
\hline 39 & DENV-4 & 160 & 160 & 5120 & 80 & 1280 & 640 & 20,480 & 640 \\
\hline 40 & DENV-4 & 640 & 1280 & 5120 & 2560 & 640 & 1280 & 20,480 & 2560 \\
\hline
\end{tabular}

Marked in gray, the highest FRNT ${ }^{90}$ titer; Red frames, serotype matching with serotype-specific neutralization.

The serotype-specificity of the neutralizing antibody response to DENV serotypes in the 80 Cambodian serum samples is summarized in Table 3 together with FRNT ${ }^{90}$ results from 39 Colombian RT-PCR positive sera. The data indicate that in 112 out of the 119 sera, 
the serotype-specific antibody response was against a heterologous DENV serotype, not in accordance with the DENV serotype identified in acute infection.

Table 3. Neutralizing specificity in sera from DENV-1-4 infected patients from Cambodia.

\begin{tabular}{ccccc}
\hline \multirow{2}{*}{$\begin{array}{c}\text { Serotype-Specific } \\
\text { Neutralization }\end{array}$} & \multicolumn{4}{c}{$\begin{array}{c}\text { Number of Sera } \\
\text { with Serotype by RT-PCR }\end{array}$} \\
\cline { 2 - 5 } & DENV-1 & DENV-2 & DENV-3 & DENV-4 \\
\hline DENV-1 & 4 & 20 & 7 & 11 \\
DENV-2 & 10 & 3 & 9 & 7 \\
DENV-3 & 7 & 7 & - & 5 \\
DENV-4 & 3 & 4 & - & - \\
DENV-1 + DENV-2 & 1 & - & 1 & 1 \\
DENV-1 + DENV-3 & 2 & - & - & 1 \\
DENV-2 + DENV-3 & 1 & - & - & 1 \\
DENV-2 + DENV-4 & 6 & - & 4 & - \\
DENV-3 + DENV-4 & - & 1 & - & - \\
$>2$ serotypes & 1 & - & - & - \\
negative & 2 & - & & - \\
\hline Total number of sera & 37 & 35 & 21 & 26 \\
\hline
\end{tabular}

Red frames, number of matching results, -, negative.

\subsection{Neutralization of Heterologous and Homologous Serotypes Using DENV-1 Positive Sera}

From 33 DENV-1 positive Cambodian patients, sufficient volumes of the second serum sample were available from the IPC Biobank to perform neutralization assays using the twelve DENV serotypes as listed in Table 1. The aim was to compare the neutralization of DENVs between the reference panel of viruses (REF) and the two sets of viruses isolated from patients in Cambodia, which were designated IPC A and IPC B (Table 1). The FRNT ${ }^{90}$ titers for each serum sample against the twelve DENV serotypes are given in Table 4. Clear matching FRNT ${ }^{90}$ titers to the infecting DENV-1 were seen with the reference DENV-1 strain 16007 in only six of the 33 serum samples. All other sera showed predominant neutralization to heterologous viruses or were double-positive. The neutralizing-specificity observed by using the three sets of viruses is summarized in Table 5. We observed a clear shift to non-DENV-1 specificity with the IPC A and IPC B set of viruses. In addition, the DENV-1 neutralizing specificity observed in double-positive sera (DENV-1 + 2; DENV-1 + 4, Table 4) completely disappeared after testing antibody-dependent neutralization with IPC $A$ and IPC B viruses. Thus, using homologous viruses for virus neutralization (viruses and sera collected at the same time and in the same endemic region), it becomes more persuasive that serum neutralization is not predominantly directed against the infecting, the last current serotype that was detected in the serum sample.

\subsection{Neutralizing Antibody Responses and Serotype Specificity in Late Serum Samples}

In this experiment, we tested paired sera collected at a longer time interval, as shown in Figure 2. Second sera were collected between days 16 and 37 after onset of fever. All first sera were from early days of infection (days 3-5), and in these sera, DENV was detected and classified by a commercial RT-PCR diagnostic kit (RealStar Dengue RT-PCR Kit 1.0, altona Diagnostics, Hamburg, Germany). All sera were tested for antibody-dependent neutralization using the reference panel of DENV serotypes (Table 1), and the FRNT ${ }^{90}$ was carried out in the same way as for the Cambodian paired sera, as shown in Table 2. 
Table 4. Neutralization titers in second sera from DENV-1-infected Cambodian patients.

\begin{tabular}{|c|c|c|c|c|c|c|c|c|c|c|c|c|}
\hline \multirow[t]{2}{*}{ 心 } & \multicolumn{4}{|c|}{$\begin{array}{c}\text { REF } \\
\text { DENV }\end{array}$} & \multicolumn{4}{|c|}{$\begin{array}{l}\text { IPC A } \\
\text { DENV }\end{array}$} & \multicolumn{4}{|c|}{$\begin{array}{l}\text { IPC B } \\
\text { DENV }\end{array}$} \\
\hline & 1 & 2 & 3 & 4 & 1 & 2 & 3 & 4 & 1 & 2 & 3 & 4 \\
\hline 24 & 640 & 2560 & $<20$ & 160 & 80 & 1280 & 640 & $<20$ & 40 & 1280 & 640 & 20 \\
\hline 14 & 80 & 2560 & 40 & 160 & 20 & 2560 & 320 & $<20$ & $<20$ & 2560 & 640 & $<20$ \\
\hline 17 & 80 & 5120 & $<20$ & 320 & $<20$ & 5120 & 1280 & 20 & $<20$ & 5120 & 1280 & $<20$ \\
\hline 25 & 2560 & 10,240 & 80 & 320 & 80 & 5120 & 2560 & $<20$ & 80 & 10,240 & 2560 & 20 \\
\hline 22 & 160 & 5120 & 20 & 160 & $<20$ & 10,240 & 320 & 20 & $<20$ & 5120 & 640 & 40 \\
\hline 16 & 80 & 640 & 2560 & 320 & 80 & 640 & 2560 & $<20$ & 40 & 80 & 5120 & $<20$ \\
\hline 23 & 640 & 640 & 2560 & 640 & 40 & 640 & 5120 & $<20$ & 20 & 80 & 5120 & 40 \\
\hline 30 & 640 & 320 & 10,240 & 160 & 40 & 320 & 10,240 & 20 & 20 & 40 & 10,240 & 40 \\
\hline 15 & 1280 & 320 & 10,240 & 160 & 40 & 320 & 20,480 & 20 & 40 & 320 & 20,480 & 160 \\
\hline 13 & $<20$ & 80 & $<20$ & 40 & $<20$ & 160 & 80 & $<20$ & $<20$ & 80 & 80 & 20 \\
\hline 03 & 20 & 320 & $<20$ & 160 & $<20$ & 320 & 80 & $<20$ & $<20$ & 80 & 80 & $<20$ \\
\hline 31 & 320 & 1280 & $<20$ & 320 & $<20$ & 1280 & 160 & 20 & $<20$ & 640 & 640 & 20 \\
\hline 33 & 640 & 2560 & $<20$ & 320 & 20 & 2560 & 320 & $<20$ & 20 & 1280 & 1280 & 20 \\
\hline 01 & $<20$ & 80 & $<20$ & 40 & $<20$ & 80 & 40 & $<20$ & $<20$ & $<20$ & 80 & 20 \\
\hline 29 & 320 & 2560 & $<20$ & 160 & 20 & 2560 & 640 & $<20$ & $<20$ & 320 & 1280 & 20 \\
\hline 21 & 160 & 640 & 160 & 320 & 40 & 640 & 1280 & $<20$ & 20 & 160 & 1280 & 20 \\
\hline 04 & 320 & 640 & $<20$ & 80 & 40 & 640 & 640 & $<20$ & 40 & 160 & 640 & $<20$ \\
\hline 08 & $<20$ & 160 & $<20$ & 160 & $<20$ & 320 & 160 & $<20$ & $<20$ & 80 & 160 & $<20$ \\
\hline 20 & 20 & 80 & $<20$ & 1280 & $<20$ & 80 & 320 & 20 & $<20$ & 40 & 320 & 160 \\
\hline 19 & 40 & 320 & $<20$ & 1280 & $<20$ & 320 & 320 & 40 & $<20$ & 40 & 320 & 160 \\
\hline 09 & $<20$ & $<20$ & $<20$ & 20 & $<20$ & $<20$ & $<20$ & $<20$ & $<20$ & $<20$ & $<20$ & $<20$ \\
\hline 28 & 160 & 160 & $<20$ & 2560 & $<20$ & 160 & 160 & 80 & $<20$ & 40 & 320 & 640 \\
\hline 12 & 20 & 80 & $<20$ & 640 & $<20$ & 80 & 160 & 20 & $<20$ & 40 & 160 & 160 \\
\hline 05 & 2560 & 640 & 40 & 80 & 640 & 640 & 640 & $<20$ & 640 & 320 & 1280 & 20 \\
\hline 26 & 640 & 640 & $<20$ & 80 & 40 & 640 & 320 & $<20$ & 40 & 320 & 640 & 20 \\
\hline 18 & 640 & 640 & 640 & 320 & 20 & 640 & 5120 & $<20$ & 20 & 80 & 1240 & 80 \\
\hline 07 & 2560 & 640 & 20 & 80 & 160 & 320 & 1280 & $<20$ & 320 & 320 & 1280 & 20 \\
\hline 11 & 640 & 160 & $<20$ & 80 & 20 & 160 & 320 & $<20$ & 20 & 80 & 320 & $<20$ \\
\hline 32 & 2560 & 80 & 20 & 160 & 80 & 80 & 320 & $<20$ & 40 & 20 & 1280 & 40 \\
\hline 06 & 640 & 160 & 20 & 80 & 160 & 160 & 640 & $<20$ & 160 & 40 & 1280 & 20 \\
\hline 10 & 1280 & 80 & 20 & 80 & 20 & 40 & 1280 & $<20$ & 20 & 80 & 1280 & $<20$ \\
\hline 02 & 640 & 320 & 40 & 640 & 40 & 320 & 1280 & 20 & 40 & 160 & 2560 & 40 \\
\hline 27 & 640 & 320 & 320 & 640 & 40 & 160 & 2560 & 20 & 20 & 80 & 5120 & 20 \\
\hline
\end{tabular}


Table 5. Serotype-specific neutralization in 33 DENV-1-positive Cambodian sera from Table 4.

\begin{tabular}{cccc}
\hline \multirow{2}{*}{$\begin{array}{c}\text { Serotype-Specific } \\
\text { Neutralization }\end{array}$} & REF & IPC A & IPC B \\
\cline { 2 - 4 } DENV-1 & 6 & - & - \\
DENV-2 & 13 & 13 & 5 \\
DENV-3 & 4 & 15 & 21 \\
DENV-4 & 5 & - & 1 \\
DENV-1 +2 & 1 & - & - \\
DENV-1 +4 & 2 & - & - \\
DENV-2 +3 & - & 3 & 4 \\
DENV-2 +4 & 1 & - & - \\
DENV-3 +4 & - & - & 1 \\
$>2$ serotypes & 1 & 1 & - \\
negative & - & 1 & 1 \\
\hline Total number of sera & 33 & 33 & 33 \\
\hline
\end{tabular}

Red frames, matching results for DENV-1 specificity; -, negative.

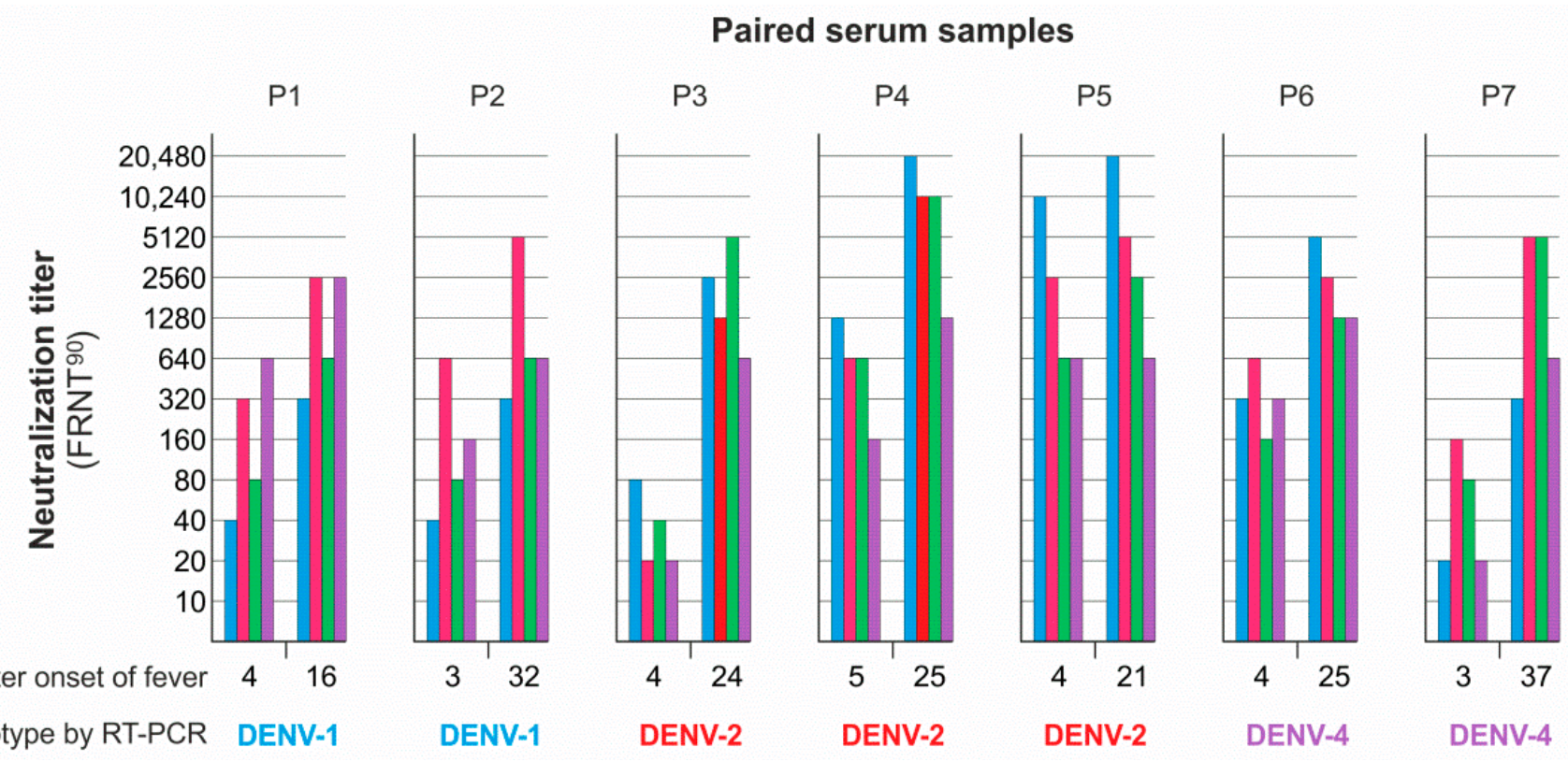

Serotype by RT-PCR DENV-1

Figure 2. Neutralization of DENV-1-4 reference strains by paired serum samples. Sera were collected from Colombian patients infected by DENV-1, DENV-2, and DENV-4 as diagnosed by RT-PCR. Viruses (REF set) used for foci reduction neutralization test (FRNT ${ }^{90}$ ): blue, DENV-1 (16007); red, DENV-2 (16881); green, DENV-3 (H87); purple, DENV-4 (H241).

In agreement with the previous $\mathrm{FRNT}^{90}$ data, the predominant neutralizing activity in the second serum sample from the Colombian patients was not directed against the serotype that was detected in acute infection. Thus, even 16 to 37 days after onset of fever, a matching, predominant neutralizing antibody response to the infecting DENV serotype could not be detected. As shown before (Table 2), we also observed a significant boost of neutralization titers but the neutralization profile was uniform in six (P1-P5, P7) of the seven paired serum samples. In the P6 samples, predominant neutralization shifted from DENV-2 to DENV-1, but neutralization specificity for the infecting DENV-4 was significantly lower in both the first and second serum samples (P6, Figure 2).

To test antibody responses against homologous epitopes, we developed two sets of antigens for the ED3 dot assay and ED3 ELISA. One set designated REF ED3.1-4 represented the ED3 domains of the reference panel of viruses and another set, designated 
COL, represented the ED3 domains of Colombian DENV strains. Colombian ED3 sequences were taken from the NCBI database, and those showing the highest degree of diversity to the REF ED3 sequences were chosen for cloning and expression. The ED3 sequences and the amino acid differences between REF ED3and COL ED3 antigens are depicted in Figure 3.

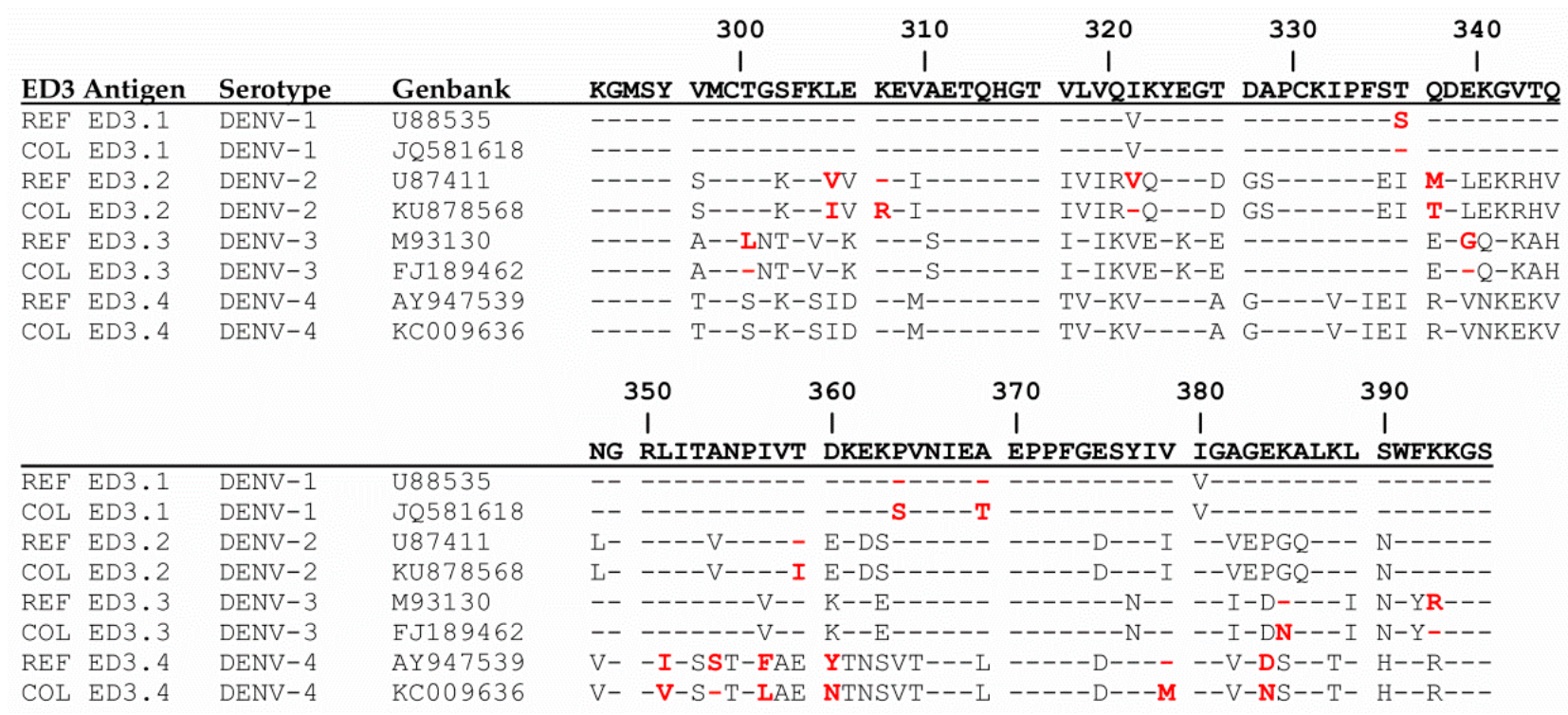

Figure 3. ED3 amino acid sequences used for ED3 ELISA and ED3 dot assay. Sequence differences between the same serotype are marked in red. Amino acid differences between REF:COL for DENV-1, S339T, P364S, A369T; for DENV-2, V308I, I310R, V324I, M340T, T359I; for DENV-3, L303T, G342E, K385N, R393K; for DENV-4, I351V, F357L, Y360N, V379M, D384N.

The ELISA results showed that using the REF ED3 and COL ED3 antigens, serotypespecific reactivities were detectable (Figure 4). For serum samples P1, RT-PCR confirmed that for DENV-1, a serotype-specific but weak response against REF ED3.4 was detected in the first sample. No serotype specificity nor antibody boost was observed with the COL ED3.1-4 antigens. For P2, RT-PCR confirmed for DENV-1, we detected an overall weak boost to all eight ED3 antigens but with no serotype specificity for DENV-1. For P3, which was RT-PCR positive for DENV-2, we observed an overall boost of antibody responses against the REF ED3.1-4 antigens and could detect a clear serotype-specific reaction to COL ED3.1 and COL ED3.3. For P4 and P6, which were RT-PCR positive for DENV-2 and DENV-4 respectively, we detected REF ED3.1 and COL ED3.1, -.2, and -.3 specific responses. For P5, which was RT-PCR positive for DENV-2, the sera showed a DENV-1 specific response. For P7, which was RT-PCR positive for DENV-4, both set of antigens showed responses to ED3.1, -.2, and -.3 but not against ED3.4.

$\mathrm{P} 1-\mathrm{P} 7$ sera were also tested by the ED3 dot assay for the detection of serotype-specific antibody responses (serum dilutions 1:100). Results of the ED3 dot assay were compared to the results obtained using ED3 ELISA, FRNT ${ }^{90}$, and RT-PCR (Table 6). The best match between the antibody detection assays was observed for the FRNT ${ }^{90}$ and the ED3 Dot Assay. Especially the data from the COL ED3 Dot Assay were very close to the FRNT ${ }^{90}$ results. ED3 Dot Assay antigens used for antibody detection are presented on nitrocellulose strips in a denatured form in contrast to native ED3 antigens used in the ED3 ELISA. Thus, using denatured as well as native antigens gave no RT-PCR matching results. Interestingly, COL ED3 antigens when tested by ELISA showed a much better match to FRNT ${ }^{90}$ data compared to the REF ELISA data. This indicates that for ELISA assays, it seems to be important to use antigens that represent the actual antigen variation of DENVs present in the endemic region. For the ED3 Dot Assay, using denatured antigens, this seems to be less important. Taken together, with all three assays, no predominant antibody response directed against the infecting DENV serotype was detectable in late sera collected between 16 and 37 days after onset of fever. 

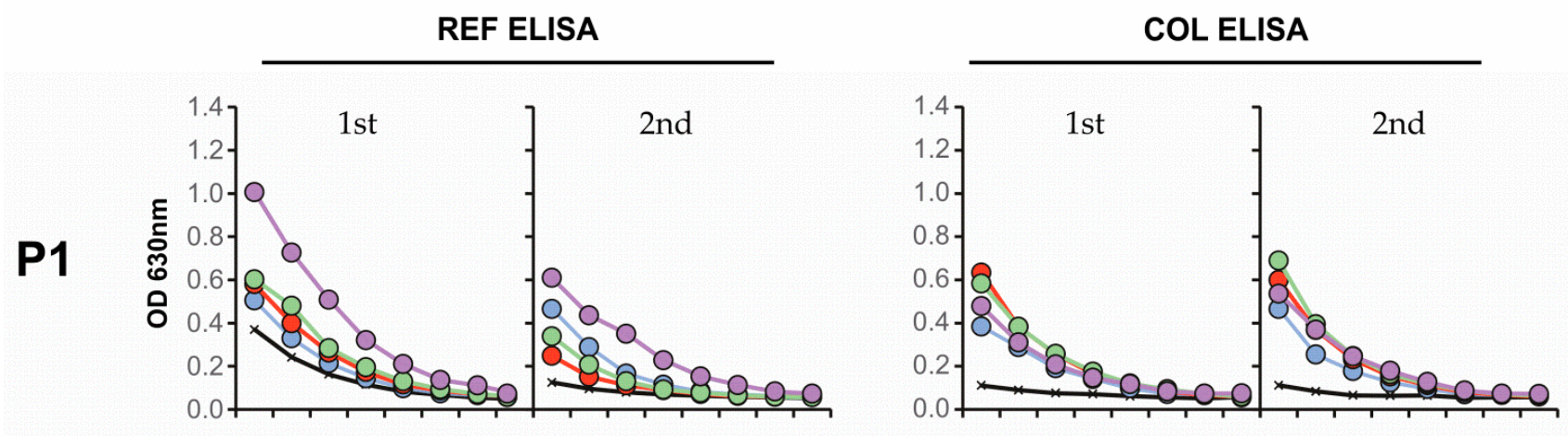

P2
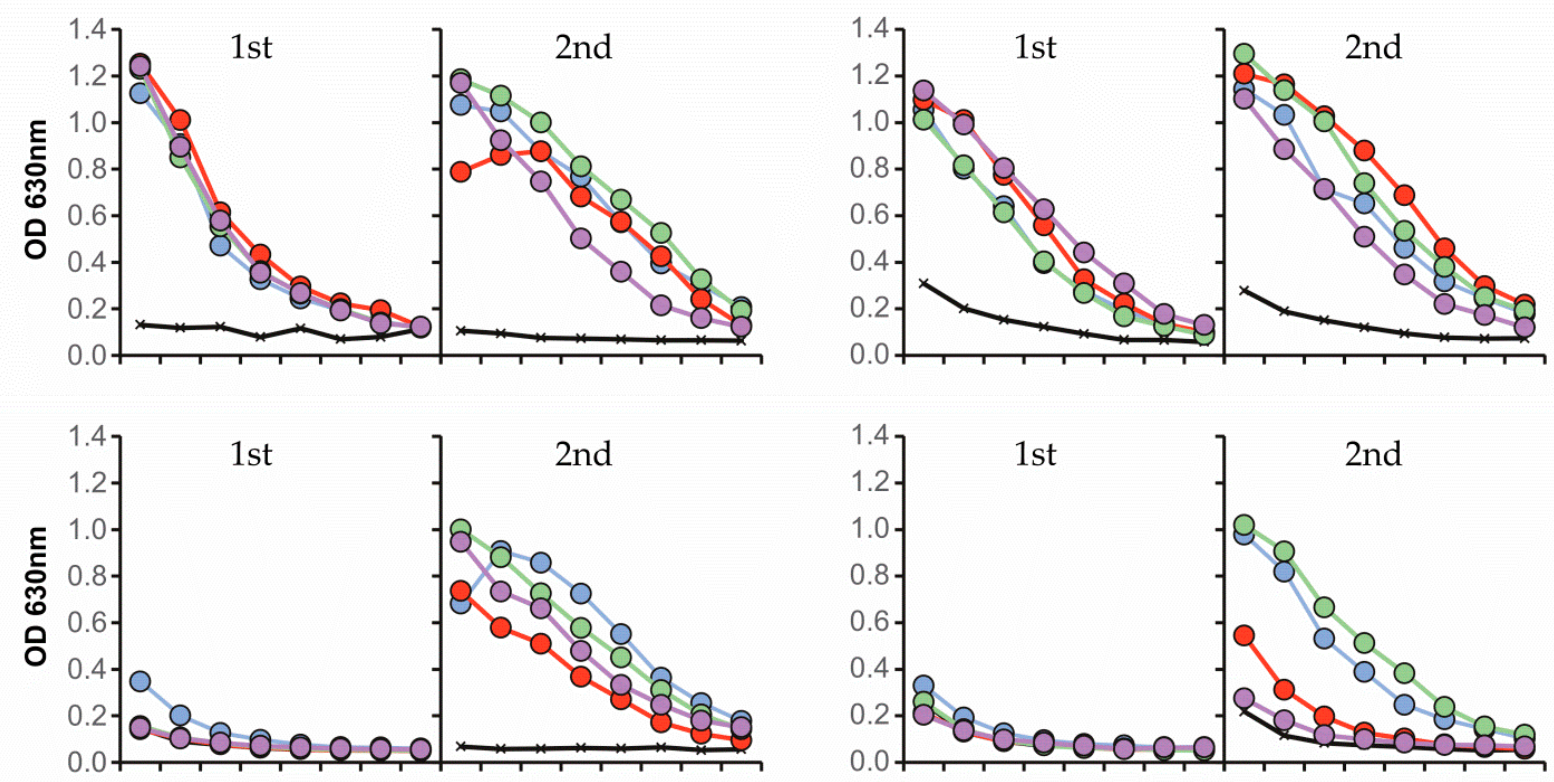

P4
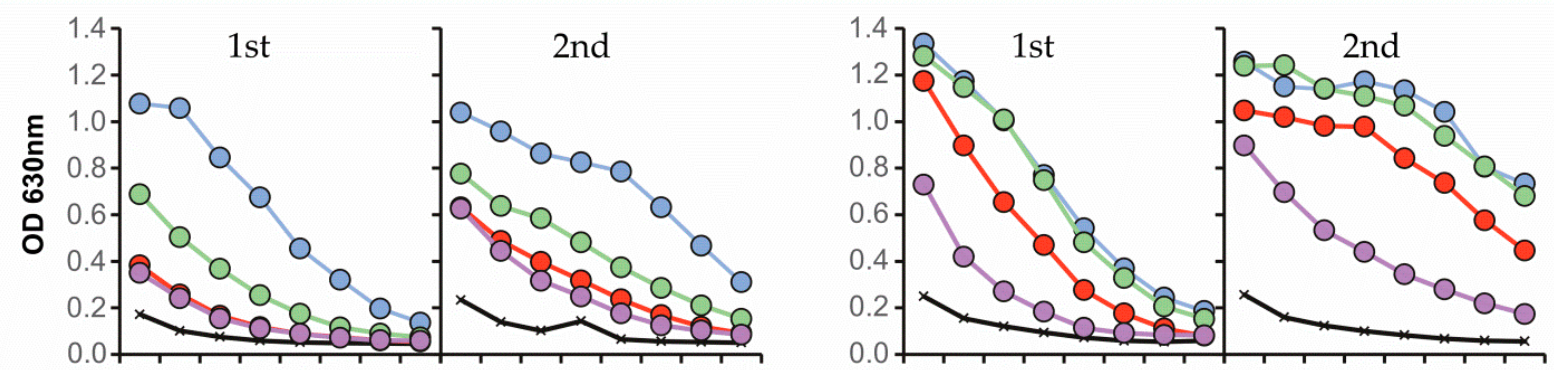

P5
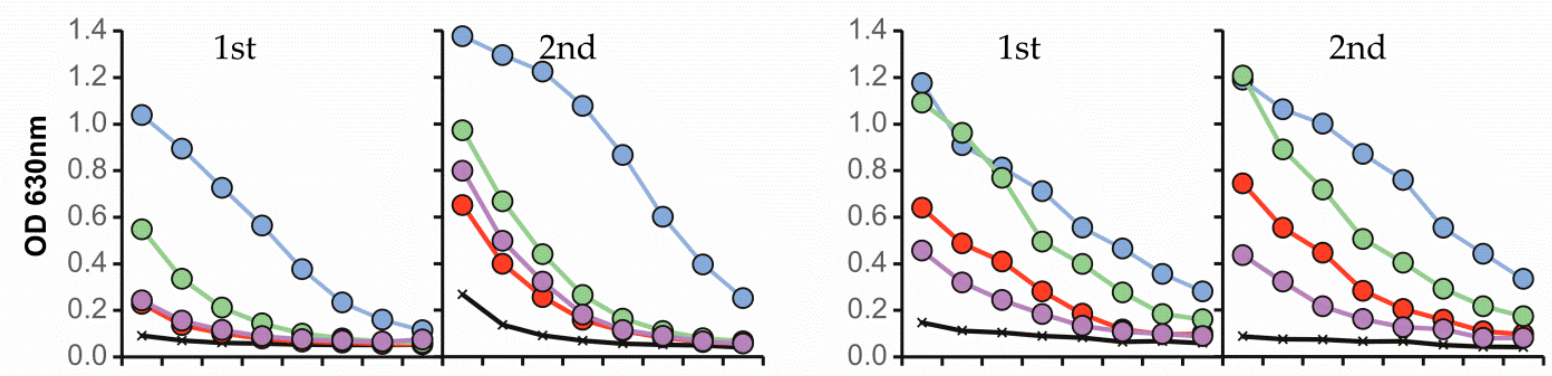

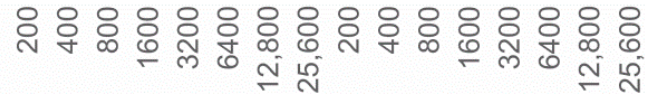

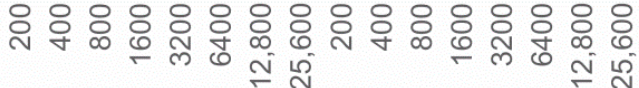
Dilution

Figure 4. Cont. 

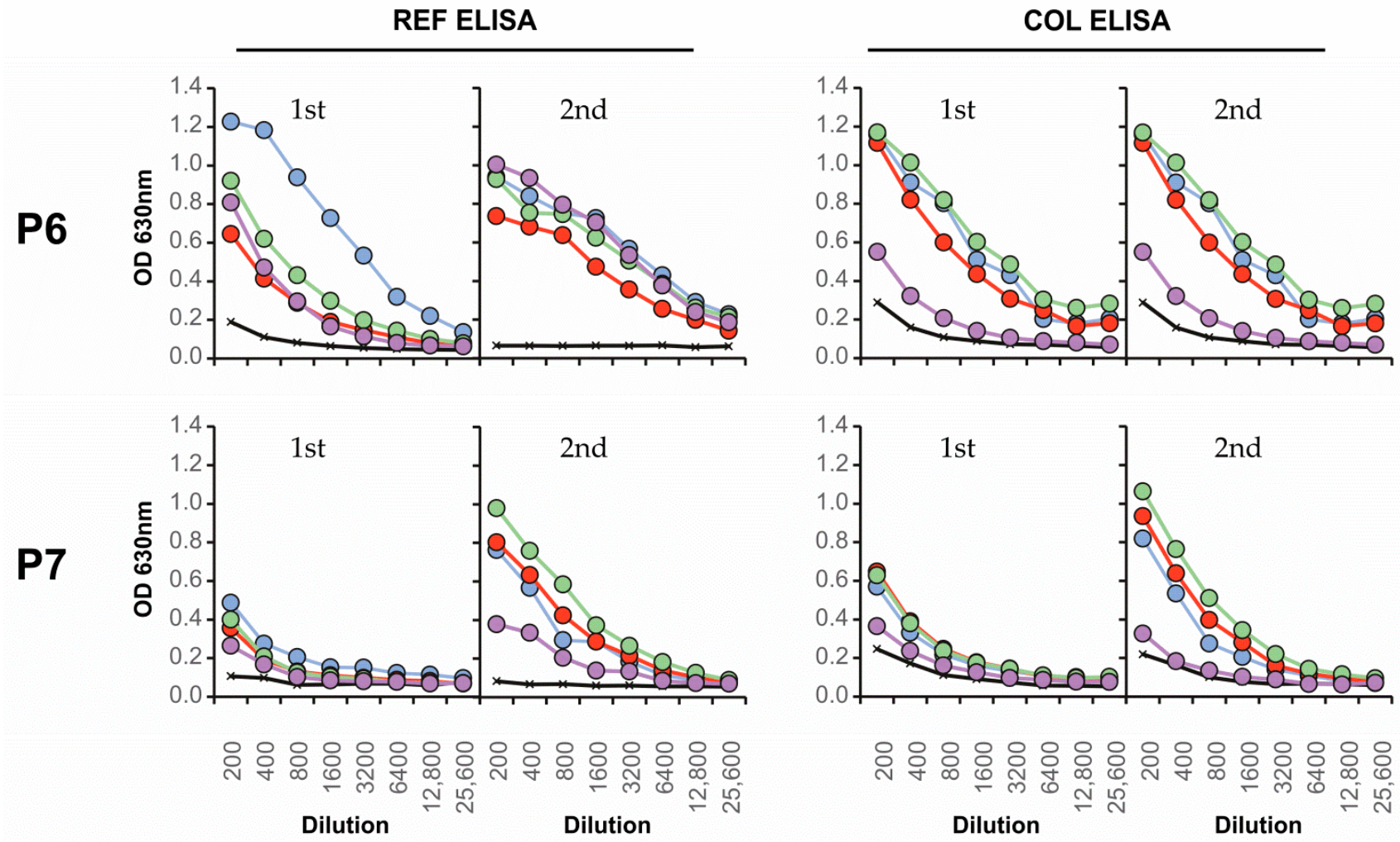

Figure 4. ED3-specific antibody detection by ED3 ELISA. Sera were collected from Colombian patients infected by DENV (P1-P7, Figure 1). Blue, ED3.1 (DENV-1); red, ED3.2 (DENV-2); green, ED3.3 (DENV-3); purple, ED3.4 (DENV-4). REF, antigens with ED3 sequences of a panel of reference strains. COL, antigens with ED3 sequences of Colombian strains. ED3 sequences and amino acid differences between REF and COL antigens are shown in Figure 2.

Table 6. Serotype specificity of antibodies in Colombian second sera P1-P7.

\begin{tabular}{cccccccc}
\hline $\begin{array}{c}\text { Colombian } \\
\text { 2nd Sera }\end{array}$ & $\begin{array}{c}\text { Serotype } \\
\text { RT-PCR }\end{array}$ & $\begin{array}{c}\text { FRNT } \\
\text { REF }\end{array}$ & REF & COL & REF & COL & Dot Assay \\
Fever
\end{tabular}

Numbers indicate DENV serotype; -, no serotype specificity was detected.

\section{Discussion}

The development of antibodies is crucial to prevent DENV entry into permissive cells through a process called antibody-dependent neutralization. Humans who become infected with a virus are starting to produce antibodies precisely binding to a variety of epitopes on multiple virus proteins, but only a subset of these antibody species have virus-neutralizing capacity. Neutralizing antibodies prevent reinfection, and this immunity lasts sometimes for the whole life. This situation becomes more complex when a virus has the capacity to easily escape from neutralization by antigenic drift or shift.

In the case of the DENV, cluster-, group-, cross-, and type-specific antibodies are developed, which can have non-neutralizing activity or can even enhance viral infection through antibody-dependent enhancement (ADE). The neutralizing antibody species plays an important role to protect humans from natural DENV infection. Therefore, measuring neutralizing antibody responses evolved by natural infection is an important task for the understanding of how the virus is priming and boosting its host. In a first attempt, we have studied antibody responses in 391 well-defined sera by a fast and simple screening 
test for neutralizing antibodies [24]. By using antigens representing domain III of the protein E from a reference panel of DENVs (REF), we have observed that neutralizing antibodies were mainly directed against a DENV serotype different from the infecting one. To further support this observation, we have performed virus neutralization tests with again four panels of sera that were characterized for infecting serotypes by RT-PCR. To compare results between laboratories, the panel of reference DENV strains was used for foci reduction neutralization assay (FRNT). In agreement with these recommendations, we also observed that the predominant antibody response against the infecting serotype was not a perfect match when we analyzed sera collected shortly after the onset of fever (1st sera) as well as sera collected about 7 days after onset of fever (2nd sera). Using the DENV reference panel, in one of 40 of sera, we found a predominant neutralization to the infecting virus. All other sera showed predominant neutralization to one of the DENVs that was not the infecting one. By analyzing the 2nd serum samples, we observed an overall boost of the DENV-neutralizing activity but no specific boosting directed against the infecting DENV serotype.

The data so far support the theory of antigenic sin, but ED3 antigens or viruses used for neutralization might be different in sequence to viruses that had originally stimulated the patients' immune response. To analyze neutralization more specifically, we have used DENV serotypes isolated from Cambodian patients changing the design of the neutralization assay from a heterologous virus-serum assay to a more homologous assay. From the IPC Biobank, serum samples are typically available in small amounts, which are still suitable to perform diagnostic tests such as the ED3 dot assay that only needs ten microliter of serum. For the standard neutralization assay, the situation is different, since much more serum is needed ( $\geq 500 \mu \mathrm{L}$ ). We could create a panel of 33 sera from DENV-1-confirmed cases to perform the homologous neutralization tests. We used eight DENV strains, two for each of the four DENV serotypes, isolated from Cambodian patients and the four reference strains for comparison. As shown before, we observed no match between the infecting DENV type and the predominant titer of neutralization. Especially with the Cambodian strains, we observed a complete mismatch, indicating that the theory that the neutralization of DENV is directed to a serotype involved in a previous infection and not to the autologous one is even more obvious when the homologous virus is tested. When we included in the assay a homologous strain (i.e., a virus that was isolated during the same epidemic season that the sera were collected), then the ability of neutralization tests to identify DENV-1 serotype was significantly lower than with the reference strains.

After subsequent DENV infection, what is measured in the early, first serum sample, unless it was collected a bit late, around day 4 to 5, would reflect past infection. It is actually common sense that in the second sera, a polyclonal heterotypic response with the highest titer directed against the most recent past infecting serotype or even the first one will be detectable. This follows the idea of original antigenic sin $[25,26]$, and it is part of the principle that the immune response will need some time to mature. The second serum collected following routine diagnostic procedures will be collected too early to see the new serotype-specific IgG becoming predominant. This is exactly what was observed in experiments with first and second sera from routine diagnostics at IPC. However, the effect of non-matching serotype-specificity was more conclusive in homologous neutralization assays than in assays using the strains from the reference panel. Moreover, we have tested sera collected several weeks after infection. In these experiments, we saw as expected a booster effect, but even after more than 14 days, the neutralization profile was identical to the neutralization profile from the early serum sample.

Strictly autologous serial challenges and neutralization studies are complicated to establish and ethically questionable. However, data from animal experiments showed clearly that serial challenges follow the rules of antigenic sin with antibody responses shifted to the new virus within 10 days [23]. Thus, in strictly autologous experiments, there is a clear picture that the immune system will develop antibodies shortly against the new strain after second or third virus challenge. 
In contrast, a study on twenty monkeys vaccinated by the tetravalent vaccine CYD showed unique neutralization profiles (pre-challenge titers) after vaccination [27]. Each animal developed a specific pre-challenge antibody profile to the tetravalent CYD antigens. This antibody profile was boosted by the DENV challenge but was still of the same profile on day 28. For example, a vaccinated animal that showed the highest pre-challenge antibody titers against DENV-1 and -3 had the same profile after DENV-2 challenge. In these experiments, the vaccine-primed response was not always shifted to the challenge virus (13 of 20) [27].

Therefore, the effect of priming and boosting by heterologous or autologous DENV strains might cause one of the problems seen also in CYD-vaccinated people [28,29]. As an example, in 2019, the FDA approved the tetravalent CYD vaccine, but with a significant limitation. The vaccine was recommended only for those who were previously infected by DENV [30,31]. Under such naturally pre-primed conditions, the immune response developed against DENV can be boosted against all four serotypes by the vaccine. This is what will be expected and was also seen in our neutralization experiments. On the other hand, naïve individuals who are primed by the vaccine will be exposed to increased risk of more severe disease through ADE. This was an unexpected result first seen in young children but was later linked to the DENV unexposed status. The strains used for CYD were the classical laboratory-adapted reference strains and are each representative for one of the four DENV serotypes, but they are antigenetically very distant from actual DENV isolates. That is probably the reason why some of the DENV strains used for CYD did not provide optimal protection and safety to the vaccinees. The strains fulfill the classical serotype requirements such as genetic diversity but are antigenetically different to the onsite present DENV strains. Thus, a more effective vaccine should represent those DENVs actually circulating in endemic areas. Another aspect where false priming might play a role would be priming against DENV by asymptomatic infections $[32,33]$ and traveling between areas where DENVs are antigenically different [34,35].

Virus-triggered antibodies are distinct from those created by vaccination, although distinguishing the two would require a new and complicated assay such as autologous neutralization assays, which might be useful to study DENV responses and neutralization in every detail. Such autologous experiments can be performed using patient isolates or pseudotyped virus. Pseudotyped viruses are ideal to study virus variation, escape from neutralization, or as part of gene delivery systems [36]. From RT-PCR-derived DNA or just sequence data, envelopes matching the patients virus and antibody response can be expressed and used to produce DENV- [37] or HIV-based pseudotypes [38]. Our data support once again the theory of original antigenic sin but also showed that an established neutralization profile to DENV-1-4 was not changed, or shifted toward the new infecting DENV strain. This effect was much better seen with homologous than heterologous DENV strains.

Author Contributions: Conceptualization, M.S.; Data curation, H.A., L.K. and M.S.; Formal analysis, H.A., I.R., S.S. and M.S.; Funding acquisition, P.B. and M.S.; Resources, P.B., S.K., J.H., I.R. and S.S.; Software, L.K. and S.S.; Writing original draft, H.A., P.B. and M.S. All authors have read and agreed to the published version of the manuscript.

Funding: This research was funded in part by the European Commission Seventh Framework Program FP7/2007-2013 for the DENFREE project under Grant Agreement n 282378 by a grant to M.S. and P.B.

Institutional Review Board Statement: The study was conducted in accordance with the Declaration of Helsinki. The use of anonymized human sera from Cambodian and Columbian patients was approved by the Cambodian National Ethics Committee and by the local Ethic Commission (Comite de Ethica) of the Hospital Rosario Pumarejo de Lopez in Vallendupar, Cesar in Colombia (2013). Viruses used (REF, Table 1) were from the virus repository of the Bernhard Nocht Institute for Tropical Medicine (BNITM) in Hamburg, Germany and all other viruses (IPC A, IPC B, Table 1) were provided by P. Buchy from IPC in Phnom Penh, Cambodia, covered by a Material Transfer Agreement between P. Buchy (IPC) and M. Schreiber (BNITM). The study was part of the EU FP7 DENFREE project $\mathrm{n}$ 
282378 and was in general supervised following EU regulations by an Ethics Board for European Contracts Evaluation at the Institute Pasteur in Paris (France) guided by Virginie Pirard (2013). VeroB4 cells were obtained from the German Collection of Microorganisms and Cell Cultures $\mathrm{GmbH}$ (DSMZ), Braunschweig, Germany.

Informed Consent Statement: Informed consent was obtained from all subjects involved in the study. Sera used were all anonymized thus no patient can be identified by the present publication.

Data Availability Statement: Raw data to neutralization and antibody responses are given in our figures and tables.

Acknowledgments: We thank all patients from Cambodia and Colombia who were willing to participate in the serum collections. We are grateful to late Ngan Chantha and Huy Rekol from the National Dengue Surveillance Program in Cambodia for their contribution to establish the Dengue Biobank at the Institut Pasteur in Cambodia (IPC). We thank Kerstin Krausz at the Bernhard Nocht Institute for Tropical Medicine for excellent technical assistance.

Conflicts of Interest: The authors declare no conflict of interest.

\section{Appendix A}

Table A1. Oligonucleotides for the cloning of COL MBP-ED3 fusion proteins.

\begin{tabular}{|c|c|}
\hline DENV-1 & \\
\hline Oligo-1 & $\begin{array}{l}\text { 5'-AAG GGG ATG TCA TAT GTG ATG TGC ACA GGC TCA TTT AAG CTA GAG AAG GAA GTG GCT } \\
\text { GAG AC-3' }\end{array}$ \\
\hline Oligo-2 & $\begin{array}{l}\text { 5'-CGC GTC TGT TCC TTC GTA TTT GAC CTG CAC TAG AAC AGT TCC ATG CTG GGT CTC AGC } \\
\text { CAC TTC CTT CTC T-3' }\end{array}$ \\
\hline Oligo-3 & 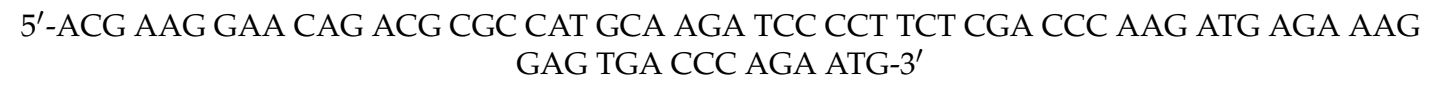 \\
\hline Oligo-4 & $\begin{array}{c}\text { 5'-GAC TGA TTT TTC TTT GTC AGT AAC TAT GGG ATT GGC TGT TAT CAA TCT CCC ATT CTG } \\
\text { GGT CAC TCC TTT C-3' }\end{array}$ \\
\hline Oligo-5 & $\begin{array}{l}\text { 5'-TTA CTG ACA AAG AAA AAT CAG TCA ACA TTG AGA CAG AAC CAC CTT TTG GTG AGA } \\
\text { GCT ACA TCG TGG TAG GGG CAG-3' }\end{array}$ \\
\hline Oligo-6 & 5'-GCT TCC TTT CTT GAA CCA GCT TAG TTT CAA GGC TTT TTC ACC TGC CCC TAC CAC GAT-3' \\
\hline Oligo-7 BamHI-for & 5'-CAC GGA TCC AAG GGG ATG TCA TAT GTG ATG TG-3' \\
\hline Oligo-8 HindIII-rev & 5'-CAC AAG CTT GCT TCC TTT CTT GAA CCA GCT-3' \\
\hline \multicolumn{2}{|l|}{ DENV-2 } \\
\hline Oligo-1 & $\begin{array}{l}\text { 5'-TCA TAC TCT ATG TGT ACA GGA AAG TTT AAA ATT GTG AGA GAA ATA GCA GAA ACA } \\
\text { CAA CAT G-3' }\end{array}$ \\
\hline Oligo-2 & $\begin{array}{l}\text { 5'-CAT GGA GAA CCG TCC CCT TCA TAT TGT ATT CTG ATA ACT ATT GTT CCA TGT TGT GTT } \\
\text { TCT GCT ATT TCT C-3' }\end{array}$ \\
\hline Oligo-3 & $\begin{array}{l}5^{\prime} \text {-GGG GAC GGT TCT CCA TGT AAG ATC CCT TTT GAA ATA ACA GAC TTG GAA AAA AGA } \\
\text { CAC GTC TTA GGT CGC-3' }\end{array}$ \\
\hline Oligo-4 & $\begin{array}{l}\text { 5'-CTA TGT TGA CTG GGC TAT CTT TTT CTA TTA CGA TTG GGT TAA CTG TAA TCG GCG ACC } \\
\text { TAA GAC GTG TCT TTT TT-3' }\end{array}$ \\
\hline Oligo-5 & 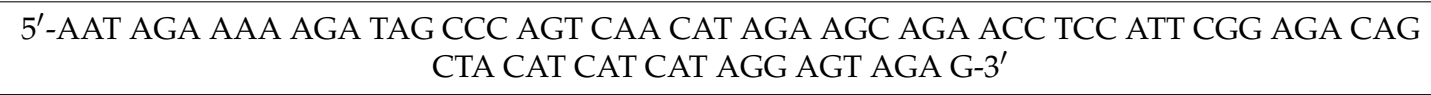 \\
\hline Oligo-6 & $\begin{array}{l}\text { 5'-ACT TCC CTT CTT AAA CCA ATT GAG TTT CAA TTG TCC CGG CTC TAC TCC TAT GAT GAT } \\
\text { GTA GCT GT-3' }\end{array}$ \\
\hline Oligo-7 BamHI-for & 5'-CAC GGA TCC TCA TAC TCT ATG TGT ACA GGA AAG TTT AAA-3' \\
\hline Oligo-8 HindIII-rev & 5'-GTG AAG CTT ACT TCC CCT CTT AAA CCA ATT GAG T-3' \\
\hline
\end{tabular}


Table A1. Cont.

\begin{tabular}{|c|c|}
\hline DENV-3 & \\
\hline Oligo-1 & 5'-AAG GGG ATG AGC TAT GCA ATG TGC ACG AGT ACC TTT GTG TTG-3' \\
\hline Oligo-2 & $\begin{array}{c}\text { 5'-ATG AGT ATT GTC CCA TGT TGC GTT TCT GAG ACT TCT TTC TTC AAC ACA AAG GTA CTC } \\
\text { GTG C-3' }\end{array}$ \\
\hline Oligo-3 & $\begin{array}{l}\text { 5'-CGC AAC ATG GGA CAA TAC TCA TCA AGG TCG AGT ACA AAG GGG AAG ATG TAC CTT } \\
\text { GCA AG-3' }\end{array}$ \\
\hline Oligo-4 & $\begin{array}{l}\text { 5'-TGT GAG CTT TCC CTT GTC CAT CCT CTG TGG AGA AAG GAA TCT TGC AAG GTA CAT CTT } \\
\text { CCC C-3' }\end{array}$ \\
\hline Oligo-5 & 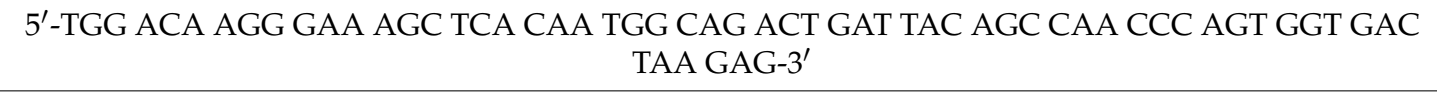 \\
\hline Oligo-6 & $\begin{array}{c}\text { 5'-CCA AAA GGA GGT TCA GCC TCA ATA TTG ACA GGC TCC TCC CTC TTA GTC ACC ACT GGG } \\
\text { TTG-3' }\end{array}$ \\
\hline Oligo-7 & $\begin{array}{l}\text { 5'-TGA GGC TGA ACC TCC TTT TGG GGA AAG TAA TAT AGT AAT TGG AAT TGG AGA CAA CGC } \\
\text { CTT- } 3^{\prime}\end{array}$ \\
\hline Oligo-8 & 5'-GCT TCC CTT CTT GTA CCA GTT GAT TTT CAA GGC GTT GTC TCC AAT TCC-3' \\
\hline Oligo-9 BamHI-for & 5'-CACGGATCCA AGGGGATGAG CTATGCAATG-3' \\
\hline Oligo-10 HindIII-rev & 5'-GTGAAGCTTG CTTCCCTTCT TGTACCAGTT G-3' \\
\hline \multicolumn{2}{|l|}{ DENV-4 } \\
\hline Oligo-1 & $\begin{array}{l}\text { 5'-AAA GGT ATG TCT TAC ACG ATG TGT TCG GGC AAG TTT AGT ATT GAT AAA GAA ATG GCG } \\
\text { GAA ACG-3' }\end{array}$ \\
\hline Oligo-2 & $\begin{array}{c}\text { 5'-GGG GGC TCC CGC CCC TTC GTA TTT GAC TTT CAC CAC TGT CGT TCC GTG CTG CGT TTC } \\
\text { CGC CAT TTC TTT ATC-3' }\end{array}$ \\
\hline Oligo-3 & $\begin{array}{l}\text { 5'-CGA AGG GGC GGG AGC CCC CTG TAA AGT CCC CAT TGA AAT TCG GGA CGT GAA CAA } \\
\text { GGA GAA AGT CGT AGG-3' }\end{array}$ \\
\hline Oligo-4 & $\begin{array}{l}5^{\prime} \text {-CTA TAT TCG TGA CAC TGT TCG TAT TTT CTG CCA GAG GTG TTG CAG AGA TCA CAC GTC } \\
\text { CTA CGA CTT TCT CCT TGT TC-3' }\end{array}$ \\
\hline Oligo-5 & $\begin{array}{l}\text { 5'-CGA ACA GTG TCA CGA ATA TAG AAC TTG AAC CGC CCT TTG GCG ACA GCT ATA TAA TGA } \\
\text { TAG GGG TGG GC-3' }\end{array}$ \\
\hline Oligo-6 & $\begin{array}{l}\text { 5'-CGA TCC TTT TCT GAA CCA ATG AAG GGT TAA TGC AGA ATT G CC CAC CCC TAT CAT TAT } \\
\text { ATA GC- } 3^{\prime}\end{array}$ \\
\hline Oligo-7 BamHI-for & 5'-CAC GGA TCC AAA GGT ATG TCT T-3' \\
\hline Oligo-8 HindIII-rev & 5'-CAC AAG CTT CGA TCC TTT TCT G-3' \\
\hline
\end{tabular}

\section{References}

1. Calisher, C.H.; Karabatsos, N.; Dalrymple, J.M.; Shope, R.E.; Porterfield, J.S.; Westaway, E.G.; Brandt, W.E. Antigenic Relationships between Flaviviruses as Determined by Cross-neutralization Tests with Polyclonal Antisera. J. Gen. Virol. 1989, 70, 37-43. [CrossRef]

2. Russell, P.K.; Nisalak, A. Dengue virus identification by the plaque reduction neutralization test. J. Immunol. 1967, 99, $291-296$.

3. Henchal, E.A.; Gentry, M.K.; McCown, J.M.; Brandt, W.E. Dengue virus-specific and flavivirus group determinants identified with monoclonal antibodies by indirect immunofluorescence. Am. J. Trop. Med. Hyg. 1982, 31, 830-836. [CrossRef]

4. Henchal, E.A.; McCown, J.M.; Seguin, M.C.; Gentry, M.K.; Brandt, W.E. Rapid identification of dengue virus isolates by using monoclonal antibodies in an indirect immunofluorescence assay. Am. J. Trop. Med. Hyg. 1983, 32, 164-169. [CrossRef]

5. Nawa, M.; Ichikawa, Y.; Inouye, S. Serotyping of dengue viruses by an enzyme-linked immunosorbent assay. Jpn. J. Med. Sci. Biol. 1985, 38, 217-221. [CrossRef]

6. Santiago, G.A.; Vergne, E.; Quiles, Y.; Cosme, J.; Vazquez, J.; Medina, J.F.; Medina, F.; Colón, C.; Margolis, H.; Muñoz-Jordán, J.L. Analytical and Clinical Performance of the CDC Real Time RT-PCR Assay for Detection and Typing of Dengue Virus. PLoS Negl. Trop. Dis. 2013, 7, e2311. [CrossRef]

7. Zolla-Pazner, S.; Gorny, M.K.; Nyambi, P.N.; VanCott, T.C.; Nádas, A. Immunotyping of human immunodeficiency virus type 1 (HIV): An approach to immunologic classification of HIV. J. Virol. 1999, 73, 4042-4051. [CrossRef] 
8. Nyambi, P.N.; Nádas, A.; Mbah, H.A.; Burda, S.; Williams, C.; Gorny, M.K.; Zolla-Pazner, S. Immunoreactivity of intact virions of human immunodeficiency virus type 1 (HIV-1) reveals the existence of fewer HIV-1 immunotypes than genotypes. J. Virol. 2000, 74, 10670-10680. [CrossRef]

9. Katzelnick, L.C.; Fonville, J.M.; Gromowski, G.D.; Arriaga, J.B.; Green, A.; James, S.L.; Lau, L.; Montoya, M.; Wang, C.; VanBlargan, L.A.; et al. Dengue viruses cluster antigenically but not as discrete serotypes. Science 2015, 349, 1338-1343. [CrossRef]

10. Tsai, W.-Y.; Durbin, A.; Tsai, J.-J.; Hsieh, S.-C.; Whitehead, S.; Wang, W.-K. Complexity of Neutralizing Antibodies against Multiple Dengue Virus Serotypes after Heterotypic Immunization and Secondary Infection Revealed by In-Depth Analysis of Cross-Reactive Antibodies. J. Virol. 2015, 89, 7348-7362. [CrossRef]

11. Morens, D.M.; Halstead, S.B.; Repik, P.M.; Putvatana, R.; Raybourne, N. Simplified plaque reduction neutralization assay for dengue viruses by semimicro methods in BHK-21 cells: Comparison of the BHK suspension test with standard plaque reduction neutralization. J. Clin. Microbiol. 1985, 22, 250-254. [CrossRef]

12. Patel, B.; Longo, P.; Miley, M.J.; Montoya, M.; Harris, E.; de Silva, A.M. Dissecting the human serum antibody response to secondary dengue virus infections. PLoS Negl. Trop. Dis. 2017, 11, e0005554. [CrossRef]

13. Guzman, M.G.; Alvarez, M.; Rodriguez-Roche, R.; Bernardo, L.; Montes, T.; Vazquez, S.; Morier, L.; Alvarez, A.; Gould, E.A.; Kourí, G.; et al. Neutralizing Antibodies after Infection with Dengue 1 Virus. Emerg. Infect. Dis. 2007, 13, 282-286. [CrossRef]

14. Imrie, A.; Meeks, J.; Gurary, A.; Sukhbaatar, M.; Truong, T.T.; Cropp, C.B.; Effler, P. Antibody to dengue 1 detected more than 60 years after infection. Viral Immunol. 2007, 20, 672-675. [CrossRef]

15. Katzelnick, L.C.; Montoya, M.; Gresh, L.; Balmaseda, A.; Harris, E. Neutralizing antibody titers against dengue virus correlate with protection from symptomatic infection in a longitudinal cohort. Proc. Natl. Acad. Sci. USA 2016, 113, 728-733. [CrossRef] [PubMed]

16. Sabin, A.B. Research on dengue during World War II. Am. J. Trop. Med. Hyg. 1952, 1, 30-50. [CrossRef] [PubMed]

17. Auerswald, H.; de Jesus, A.; Seixas, G.; Nazareth, T.; In, S.; Mao, S.; Duong, V.; Clara Silva, A.; Paul, R.; Dussart, P.; et al. First dengue virus seroprevalence study on Madeira Island after the 2012 outbreak indicates unreported dengue circulation. Parasit. Vectors 2019, 12, 103. [CrossRef]

18. Libraty, D.H.; Zhang, L.; Obcena, A.; Brion, J.D.; Capeding, R.Z. Anti-dengue virus envelope protein domain III IgG ELISA among infants with primary dengue virus infections. Acta Trop. 2015, 142, 103-107. [CrossRef] [PubMed]

19. Sirivichayakul, C.; Sabchareon, A.; Limkittikul, K.; Yoksan, S. Plaque reduction neutralization antibody test does not accurately predict protection against dengue infection in Ratchaburi cohort, Thailand. Virol. J. 2014, 11, 48. [CrossRef] [PubMed]

20. Dejnirattisai, W.; Jumnainsong, A.; Onsirisakul, N.; Fitton, P.; Vasanawathana, S.; Limpitikul, W.; Puttikhunt, C.; Edwards, C.; Duangchinda, T.; Supasa, S.; et al. Cross-reacting antibodies enhance dengue virus infection in humans. Science 2010, 328, 745-748. [CrossRef]

21. Lai, C.-Y.; Tsai, W.-Y.; Lin, S.-R.; Kao, C.-L.; Hu, H.-P.; King, C.-C.; Wu, H.-C.; Chang, G.-J.; Wang, W.-K. Antibodies to Envelope Glycoprotein of Dengue Virus during the Natural Course of Infection Are Predominantly Cross-Reactive and Recognize Epitopes Containing Highly Conserved Residues at the Fusion Loop of Domain II. J. Virol. 2008, 82, 6631-6643. [CrossRef]

22. Durbin, A.P.; Karron, R.A.; Sun, W.; Vaughn, D.W.; Reynolds, M.J.; Perreault, J.R.; Thumar, B.; Men, R.; Lai, C.-J.; Elkins, W.R.; et al. Attenuation and immunogenicity in humans of a live Dengue virus type-4 vaccine candidate with a 30 nucleotide deletion in its 3-untranslated region. Am. J. Trop. Med. Hyg 2001, 65, 405-413. [CrossRef]

23. Halstead, S.B.; Casals, L.; Shotwell, H.; Palumboii, N. Studies on the immunization of monkeys against Dengue. Protection derived from single and sequential virus infections. Am. J. Trop. Med. Hyg. 1973, 22, 366-374.

24. Auerswald, H.; Klepsch, L.; Schreiber, S.; Hülsemann, J.; Franzke, K.; Kann, S.; Y., B.; Duong, V.; Buchy, P.; Schreiber, M.; et al. The Dengue ED3 Dot Assay, a Novel Serological Test for the Detection of Denguevirus Type-Specific Antibodies and Its Application in a Retrospective Seroprevalence Study. Viruses 2019, 11, 304. [CrossRef]

25. Halstead, S.B.; Rojanasuphot, S.; Sangkawibha, N. Original antigenic sin in dengue. Am. J. Trop. Med. Hyg. 1983, 32, 154-156. [CrossRef]

26. Monto, A.S.; Malosh, R.E.; Petrie, J.G.; Martin, E.T. The Doctrine of Original Antigenic Sin: Separating Good from Evil. J. Infect. Dis. 2017, 215, 1782-1788. [CrossRef] [PubMed]

27. Shi, M.; Lin, X.-D.; Vasilakis, N.; Tian, J.-H.; Li, C.-X.; Chen, L.-J.; Eastwood, G.; Diao, X.-N.; Chen, M.-H.; Chen, X.; et al. Divergent viruses discovered in arthropods and vertebrates revise the evolutionary history of the Flaviviridae and related viruses. J. Virol. 2015, 90, 659-669. [CrossRef]

28. Aguiar, M.; Stollenwerk, N.; Halstead, S. The impact of the newly licensed dengue vaccine in endemic countries. PLoS Negl. Trop. Dis. 2016, 10, e0005179. [CrossRef]

29. Aguiar, M.; Stollenwerk, N.; Halstead, S. The risks behind Dengvaxia recommendation. Lancet. Infect. Dis. 2016, 16, 882-883. [CrossRef]

30. Aguiar, M.; Halstead, S.; Stollenwerk, N. Consider stopping Dengvaxia administration without immunological screening. Expert Rev. Vaccines 2017, 16, 301-302. [CrossRef]

31. Aguiar, M.; Stollenwerk, N. Dengvaxia Efficacy Dependency on Serostatus: A Closer Look at More Recent Data. Clin. Infect. Dis. 2018, 66, 641-642. [CrossRef] [PubMed]

32. Chatchen, S.; Sabchareon, A.; Sirivichayakul, C. Serodiagnosis of asymptomatic dengue infection. Asian Pac. J. Trop. Med. 2017, 10, 11-14. [CrossRef] [PubMed] 
33. Kyaw, A.K.; Ngwe Tun, M.M.; Naing, S.T.; Htwe, T.T.; Mar, T.T.; Khaing, T.M.; Aung, T.; Aye, K.S.; Thant, K.Z.; Morita, K.; et al. Inapparent dengue virus infection among students in Mandalay, Myanmar. Trans. R. Soc. Trop. Med. Hyg. 2019. [CrossRef] [PubMed]

34. Olivero, R.M.; Hamer, D.H.; MacLeod, W.B.; Benoit, C.M.; Sanchez-Vegas, C.; Jentes, E.S.; Chen, L.H.; Wilson, M.E.; Marano, N.; Yanni, E.A.; et al. Dengue Virus Seroconversion in Travelers to Dengue-Endemic Areas. Am. J. Trop. Med. Hyg. 2016, 95, $1130-1136$. [CrossRef] [PubMed]

35. Grange, L.; Simon-Loriere, E.; Sakuntabhai, A.; Gresh, L.; Paul, R.; Harris, E. Epidemiological Risk Factors Associated with High Global Frequency of Inapparent Dengue Virus Infections. Front. Immunol. 2014, 5, 1-10. [CrossRef] [PubMed]

36. Li, Q.; Liu, Q.; Huang, W.; Li, X.; Wang, Y. Current status on the development of pseudoviruses for enveloped viruses. Rev. Med. Virol. 2018, 28, e1963. [CrossRef]

37. Mukherjee, S.; Pierson, T.C.; Dowd, K.A. Pseudo-infectious reporter virus particles for measuring antibody-mediated neutralization and enhancement of dengue virus infection. Methods Mol. Biol. 2014, 1138, 75-97.

38. Kretschmer, M.; Kadlubowska, P.; Hoffmann, D.; Schwalbe, B.; Auerswald, H.; Schreiber, M. Zikavirus prME Envelope Pseudotyped Human Immunodeficiency Virus Type-1 as a Novel Tool for Glioblastoma-Directed Virotherapy. Cancers 2020, 12, 1000. [CrossRef] [PubMed] 